Interactive comment on "Impact of $\mathrm{NO}_{\mathrm{x}}$ on secondary organic aerosol (SOA) formation from $\alpha$-pinene and $\beta$-pinene photo-oxidation: the role of highly oxygenated organic nitrates" by lida \title{
Pullinen et al.
}

lida Pullinen et al.

t.mentel@fz-juelich.de

Received and published: 15 May 2020

We thank referee\#2 for the helpful comments. Please, find our responses in the pdf-file attached. Please, see new Table 1 and new Figures 3 below.

Please also note the supplement to this comment: 
Interactive comment on Atmos. Chem. Phys. Discuss., https://doi.org/10.5194/acp-2019-1168, 2020.
ACPD

Interactive comment 


\section{ACPD}

Tables

Interactive

Table 1: Overview of $\alpha$-pinene and $\beta$-pinene experiments

comment

\begin{tabular}{|c|c|c|c|c|}
\hline Experiment Description & $\begin{array}{l}{[\mathrm{VOC}]_{0}{ }^{\mathrm{a}}} \\
{[\mathrm{ppb}]}\end{array}$ & $\begin{array}{l}{\left[\mathrm{NO}_{\mathbf{x}}\right]_{0}{ }^{\mathrm{a}} \&\left(\left[\mathrm{NO}_{\mathrm{x}}\right] \mathrm{ss} \mathrm{s}^{\mathrm{b}}\right)} \\
{[\mathrm{ppb}]}\end{array}$ & $\begin{array}{l}{\left[\mathrm{O}_{3}\right] \mathrm{ss} \mathrm{b}^{\mathrm{b}}} \\
{[\mathrm{ppb}]}\end{array}$ & $\begin{array}{l}[\mathrm{OH}]]_{\mathrm{s}}^{\mathrm{b}} \\
{\left[1 \mathrm{~cm}^{-3} \mathrm{~cm}^{-3}\right.}\end{array}$ \\
\hline $\begin{array}{l}\text { 1. Gas-phase yield of ON } \\
\text { and gas-phase } \mathrm{OrgNO}_{3} \\
\text { (Section 3.1) }\end{array}$ & $\begin{array}{l}\text { B-pinene } 39 \rightarrow 0 \\
\text { m-xylene } 3.7\end{array}$ & $\begin{array}{l}50 \\
(20 \rightarrow 30)\end{array}$ & $19 \rightarrow 30$ & $2.3 \pm 20 \%$ \\
\hline \multirow[t]{2}{*}{$\begin{array}{l}\text { 2. Formation of HOM-ON } \\
\text { (Section 3.3) }\end{array}$} & $\alpha$-pinene 16.5 & $\begin{array}{llllll}0.3 & / 7.5 & / 15.3^{c} / 26.7 / 39.7 / 45.5 \\
(0.3 & / 1.8 & / 3.7^{c} / 5.7 & / 8.7 & / 10.4) \\
/ 52.9 & / 59.1 & / 83.3 / 137.8 & & \\
(/ 12.4 / 15.8 & / 26.8 / 72.2) & & \end{array}$ & $62-152$ & $4.5-7.5$ \\
\hline & $\beta$-pinene 37 & $\begin{array}{l}3.9 / 53.8 / 113.6 / 194 \\
(1.2 / 16.5 / 37.0 / 77 .)\end{array}$ & $\begin{array}{l}\text { Not } \\
\text { determined }\end{array}$ & $\begin{array}{l}\text { Not } \\
\text { determined }\end{array}$ \\
\hline \multirow[t]{2}{*}{$\begin{array}{l}\text { 3. Effective uptake } \\
\text { coefficients }^{\mathrm{d}} \text { (Section 3.4) }\end{array}$} & $\alpha$-pinene 12.5 & $\begin{array}{l}0.3 \\
(0.3)\end{array}$ & 29 & $9.2 \pm 20 \%$ \\
\hline & B-pinene 37 & $\begin{array}{l}30 \\
(4)\end{array}$ & 49 & $8.8 \pm 20 \%$ \\
\hline \multirow[t]{2}{*}{$\begin{array}{l}\text { 4. } \mathrm{OrgNO}_{3} \text { in } \mathrm{SOA} \\
\text { (Section } 3.5)\end{array}$} & $\alpha$-pinene 46 & $\begin{array}{l}0.3 / 32.0 / 51.0 / 60.0 \\
(0.3 / 10.4 / 17.5 / 19.5)\end{array}$ & $37-62$ & $4.7-7.7$ \\
\hline & B-pinene 38 & 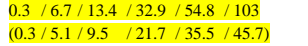 & $44-53$ & $0.9-3.7$ \\
\hline
\end{tabular}

Fig. 1. 


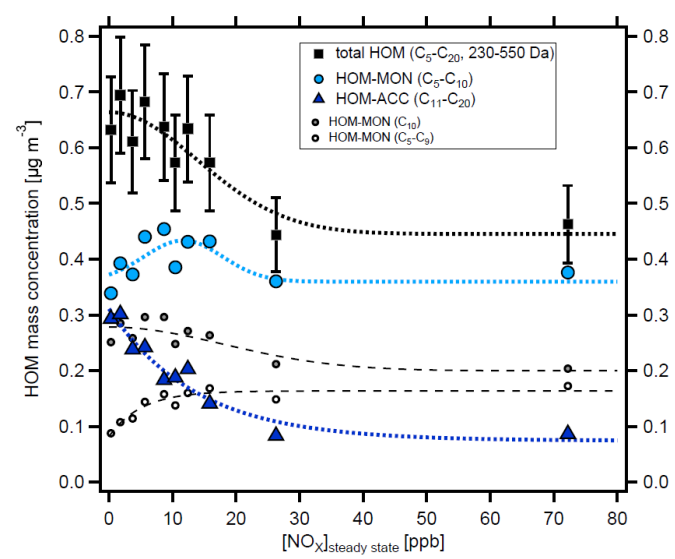

Interactive

comment

Figure 3. Mass concentration of HOM products in dependence on [NO $\left.{ }_{x}\right]_{s s}$ in $\alpha$-pinene photo-oxidation experiments. $\mathrm{C}_{5}-\mathrm{C}_{20}$ compounds with molecular masses 230-550 Da were added up for total HOM (black squares) and divided into HOM monomers (light bis) a the setal

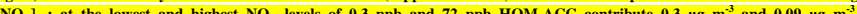
respectively, to total HOM, whereas HOM monomers contribute about $0.4 \mathrm{ug} \mathrm{m}^{-3}$ over the whole range. More than $70 \%$ of $\mathrm{HOM}$

10 ACC were suppressed at the highest $\left[\mathrm{NO}_{\mathrm{x}}\right]$ while $\mathrm{HOM}$ monomers remained about constant. The increasing impor radicals with increasing $\left[\mathrm{NO}_{\mathrm{x}}\right.$ lss is indicated by the small circles: $\mathrm{C}_{5.9}$ compounds (small open circles) arise in large parts from fragmentation of alkoxy radicals. They double from $\approx 0.9$ to $\approx 1.8 \mu^{-3} \mathrm{~m}^{-3}$ at the highest [NOx]ss, whereas the $\mathrm{C}_{10}$ compounds (grey circles) drop by only about $30 \%$. $\mathrm{C}_{5.9}$ compounds must carry at least $7 \mathrm{O}$-atoms because the lower end of the mass range is set to 230 Da which is the molecular mass of $\mathrm{C}_{10} \mathrm{H}_{14} \mathrm{O}_{6}$. Assuming that compounds in the selected mass range will contribute to SOA

15 formation, the lower $\mathrm{SOA}$ yields at high $\left[\mathrm{NO} \mathrm{O}_{\mathbf{x}}\right]$ was due to the suppression of accretion products and increasing fragmentation via peretion facters in a range of $1.1-0.8$. The corts particle surface ranged from $\sim 10 \mathrm{~m}^{2} \mathrm{~m}$ to $6 \times 10^{5} \mathrm{~m}^{2} \mathrm{~m}$. 20 correction factors at lower [NOx]ss where new particle formation could not be suppressed.

Fig. 2. 